OPEN ACCESS

Edited by:

Yves Jacquot,

Université Paris Descartes, France

Reviewed by:

Ernestina Marianna De Francesco, University of Manchester,

United Kingdom

Andrew C. B. Cato,

Karlsruhe Institute of Technology

(KIT), Germany

${ }^{*}$ Correspondence:

Dongmin Liu

doliu@vt.edu

Specialty section:

This article was submitted to

Molecular and Structural

Endocrinology,

a section of the journa

Frontiers in Endocrinology

Received: 26 November 2019

Accepted: 03 March 2020

Published: 31 March 2020

Citation:

Luo J and Liu D (2020) Does GPER

Really Function as a $G$

Protein-Coupled Estrogen Receptor in

vivo? Front. Endocrinol. 11:148

doi: 10.3389/fendo.2020.00148

\section{Does GPER Really Function as a G Protein-Coupled Estrogen Receptor in vivo?}

\author{
Jing Luo ${ }^{1,2}$ and Dongmin Liu ${ }^{2 *}$ \\ ${ }^{1}$ Department of Nutrition, School of Public Health, Sun Yat-sen University, Guangzhou, China, ${ }^{2}$ Department of Human \\ Nutrition, Foods and Exercise, College of Agricultural and Life Sciences, Virginia Tech, Blacksburg, VA, United States
}

Estrogen can elicit pleiotropic cellular responses via a diversity of estrogen receptors (ERs) - mediated genomic and rapid non-genomic mechanisms. Unlike the genomic responses, where the classical nuclear $\mathrm{ER} \alpha$ and $\mathrm{ER} \beta$ act as transcriptional factors following estrogen binding to regulate gene transcription in estrogen target tissues, the non-genomic cellular responses to estrogen are believed to start at the plasma membrane, leading to rapid activation of second messengers-triggered cytoplasmic signal transduction cascades. The recently acknowledged ER, GPR30 or GPER, was discovered in human breast cancer cells two decades ago and subsequently in many other cells. Since its discovery, it has been claimed that estrogen, ER antagonist fulvestrant, as well as some estrogenic compounds can directly bind to GPER, and therefore initiate the non-genomic cellular responses. Various recently developed genetic tools as well as chemical ligands greatly facilitated research aimed at determining the physiological roles of GPER in different tissues. However, there is still lack of evidence that GPER plays a significant role in mediating endogenous estrogen action in vivo. This review summarizes current knowledge about GPER, including its tissue expression and cellular localization, with emphasis on the research findings elucidating its role in health and disease. Understanding the role of GPER in estrogen signaling will provide opportunities for the development of new therapeutic strategies to strengthen the benefits of estrogen while limiting the potential side effects.

Keywords: GPR30, GPER, estrogen receptor, estrogen, physiological role

\section{INTRODUCTION}

Estrogen, more specifically, $17 \beta$-estradiol (E2), is a female sex hormone, which is essential for not only the development of the female reproductive organs but also the secondary sex characteristics (1). In addition, this hormone plays a critical role in the development and function of the male reproductive tract (2). Moreover, E2 plays important physiological roles in almost every part of the body, including the nervous system $(3)$, immune system $(4,5)$, skeletal tissue $(6,7)$, musculature $(8-11)$, as well as the endocrine system $(12,13)$. E2 exerts the comprehensive physiological effects by interacting with estrogen receptors (ERs) and subsequently, activating various signaling cascades that extend from seconds to hours $(14,15)$. In this review, we provide a brief overview of estrogen signaling and describe the characteristics of its receptors, emphasizing on GPR30, presumably a G protein-coupled ER (GPER). We focus on discussing studies aimed at elucidating the potential 
physiological and pathological roles of GPER in regards to its estrogen binding properties and in mediating the actions of E2 in vivo. In addition, this review also summarizes recent research that supports E2-independent effects of GPER in various tissues.

\section{ESTROGEN RECEPTORS}

Steroid hormones are synthesized in the ovaries (E2, progesterone), testes (androgens, testosterone), and adrenal glands (cortisol, androgens). E2 is a critical steroid hormone that was originally believed (in the 1960's) to exert its physiological effects through a nuclear ER, later termed as ER $\alpha$, which was identified in the rat uterus (16-18). About three decades later, the first ER $\alpha$ knockout mouse model was generated (19). The second ER, ER $\beta$, was identified in the rat prostate in 1996 (20). ERs are ligand-regulated nuclear transcriptional factors that are believed to mediate a wide array of biological actions of E2.

Besides these classical nuclear ERs, which can initiate transcriptional events in the promoter regions of target genes, E2 is also reported to engage in rapid non-genomic signaling events $(21,22)$. Several studies have shown that E2 triggers a variety of intracellular signaling events, including mobilization of intracellular calcium in MCF-7 breast cancer cells (23), production of cyclic adenosine monophosphate (cAMP) in primary rat uterine cells (24), activation of mitogen-activated protein kinases p38 in MCF-7 cells and ROS17/2.8 rat bone cell line $(25,26)$, and activation of extracellular signal-regulated kinase 1/2 (ERK 1/2) in human neuroblastoma cells (27). The underlying mechanisms for E2 exerting these rapid cellular actions appear to be complex that may involve ERs, the variants of $\mathrm{ER} \alpha$, and unknown E2 receptors $(22,28)$. Cellular signal transduction can occur as a result of E2 activating $G$ proteins, which then lead to the modulation of downstream cellular pathways (29-31). Thus, a potential role for $\mathrm{G}$ protein-coupled receptors (GPCRs), which utilize E2 as ligand, has been proposed as an important route through which E2 exerts cellular functions.

\section{GPER, AN ATYPICAL G PROTEIN-COUPLED RECEPTOR Discovery of GPER}

As early as the 1960-1970s, two independent studies reported the rapid cellular effects of E2 on cAMP synthesis (32) and calcium mobilization (33). These acute effects evoked by E2 are transmitted through enzymes and ion channels via the activation of membrane-associated ERs that may not involve transcription, which are thereby referred as non-genomic or extra-nuclear signaling pathways (34, 35). In 1997, a novel seven transmembrane-domain GPCR, named GPR30, was first identified and cloned (36), which showed high sequence homology to the interleukin 8 receptor and the angiotensin II receptor type $1(37,38)$. Therefore, it was initially speculated that the endogenous ligand activating GPR30 is a chemokine or peptide $(37,39)$. However, chemokines and/or peptides failed to evoke responses in GPR30 transfected cells $(37,39)$, suggesting that GPR30 might be an orphan GPCR without cognate endogenous ligands. In 2004, Maggiolini et al. performed gene expression analysis of SKBr3 cells lacking ERs. The results indicated that the proto-oncogene $\mathrm{c}$-fos was upregulated in response to $\mathrm{E} 2$. Interestingly, the upregulation of $\mathrm{c}$-fos by E2 was blocked when the endogenous GPR30 expression was silenced (40). In another study that used breast cancer cell lines, GPR30 expression was positively correlated with ER $\alpha$ expression, suggesting these two receptors might be regulated by the same regulatory mechanism or transcription factors (36). The orphan fate of GPR30 reached a turning point in 2005 (41). Two independent research groups provided data demonstrating that E2 directly binds to GPR30, which thus acts as a membrane-bound ER $(30,31)$. In 2007, the physiological role of GPR30 in vivo was first examined in rats (42). The results showed that administration of E2 induced GPR30 expression and attenuated hepatic injury via protein kinase A (PKA)-mediated mechanism in rats. Consistently, knockdown of GPR30 but not $\mathrm{ER} \alpha$ attenuated the E2-dependent activation of PKA in hepatocytes isolated from rats. Therefore, GPR30 was officially named as GPER by the International Union of Basic and Clinical Pharmacology in 2007 (43). The characteristics of all three known ERs are summarized in Table 1.

With the discovery of GPR30 as a novel ER (GPER), growing evidence has emerged to describe the rapid action of E2 via GPER $(15,30,36,53)$. A search in PubMed in January 2020 with the keywords "GPR30 or GPER and estrogen" yielded 1,280 publications since 1997, with $88.6 \%(1,54)$ published during the past decade. This area has attracted a surge of interest recently and represents one of the most active area in the field of $\mathrm{E} 2$ research.

\section{GPER Expression in Tissue}

The expression of GPER protein is not only restricted to E2responsive tissues, as originally speculated. It is also present in many other tissues in humans $(36-39,55,56)$ and rodents (57-62), such as brain, placenta, lung, liver, prostate, ovary, pancreatic islets, adipose tissue, vasculature, muscle, skeleton, as well as immune cells $(63,64)$. Interestingly, it appears that the expression pattern of GPER is age-, species-, gender-, or tissue-dependent. For example, the mRNA expression of GPER in skeletal muscle tends to be higher in premenopausal women compared to post-menopausal women (65). In mouse skeletal muscle, GPER mRNA abundance is almost 4 -fold greater in females than that in males (57), with greater expression of GPER mRNA in female soleus than in extensor digitorum longus muscle (EDL) (66). GPER is also highly expressed in human bone tissues, and thus it may mediate the action of E2 on preserving bone density (67), suggesting a potential therapeutic strategy to prevent or alleviate menopausal osteoporosis by targeting GPER. Moreover, a high density of GPER was detected in the brain of hamster, including hypothalamus, thalamus, cerebellum, and amygdala, and the expression pattern of GPER behaved in a sexually dimorphic fashion in both young (post-natal 7 days) and adult (post-natal 60 days) animals (68). The gene expression of GPER was significantly higher in adult female hypothalamus than that of adult male, whereas the opposite expression pattern was observed in thalamus in young hamster. Similarly, the expression 
TABLE 1 | Characteristics of ERs (44-52).

\begin{tabular}{|c|c|c|c|}
\hline ER characteristics & $\mathrm{ER} \alpha$ & ER $\beta$ & GPER \\
\hline Category & \multicolumn{2}{|c|}{ Nuclear steroid hormone receptor superfamily } & G protein-coupled receptor superfamily \\
\hline Location & Nucleus & Nucleus & Membrane-associated \\
\hline Size & 595 aa & 530 aa & 375 aa \\
\hline Numbers of isoforms & 3 & 5 & 1 \\
\hline Chromosome region & $6 q 25.1$ & $14 q 23.2$ & $7 \mathrm{p} 22.3$ \\
\hline Structure & \multicolumn{2}{|c|}{ DNA-binding domain, ligand-binding domain, $\mathrm{N}$-terminal domain } & $\begin{array}{l}7 \text { transmembrane } \alpha \text {-helical regions, } 4 \\
\text { extracellular and } 4 \text { cytosolic segments }\end{array}$ \\
\hline Distribution in tissues & $\begin{array}{l}\text { Hypothalamus, hippocampus, testes, ovary, } \\
\text { endometrium, uterus, prostate, kidney, liver, breast, } \\
\text { epididymis, muscle, adipose tissue }\end{array}$ & $\begin{array}{l}\text { Testes, ovary, prostate, vascular } \\
\text { endothelium, bladder, colon, adrenal } \\
\text { gland, pancreas, muscle, adipose } \\
\text { tissue }\end{array}$ & $\begin{array}{l}\text { Central and peripheral nervous system, uterus, } \\
\text { ovary, mammary glands, testes, pancreas, } \\
\text { kidney, liver, adrenal and pituitary glands, } \\
\text { cardiovascular system, adipose tissue }\end{array}$ \\
\hline
\end{tabular}

pattern of GPER mRNA displayed contrary trend in cerebellum and amygdala areas in young hamster between male and female (68). However, it is presently unclear whether GPER shows a similar expression pattern in humans. Interestingly, GPER expression is developmentally regulated. In the mammary gland, GPER abundance is lower in the elongating ducts during puberty and then increases through periods of sexual maturity (15). In the cartilage of the human growth plate, GPER expression decreases as puberty progresses in both genders (69). Studies have shown that GPER expression level in mammary ductal epithelia is dependent on estrous cycle (15), and consistently, the highest GPER mRNA expression level was found on day 3 of estrous cycle and then declined to the lowest level on day 12 in equine endometrium (70). Results from another study examining GPER expression in hamster ovarian cells during estrous cycle exhibited similar pattern that GPER mRNA and protein abundance reached the peak levels on day 3 of estrous cycle and decreased on day 4 . These findings are very important, as they provide a basis for investigating the physiological or pathological roles of GPER including cancer development, immune regulation, and reproductive, cardiovascular, as well as metabolic functions $(64,71)$.

\section{GPER Localization in Cells}

GPER is a seven transmembrane GPCR and therefore it is presumed to be located on the plasma membrane (72) as are most GPCRs $(30,73)$. Indeed, it has been shown that GPER induces signaling via activation of $\mathrm{G} \alpha$ s or $\mathrm{G} \alpha \mathrm{i}(15,30)$, strongly suggesting that this receptor is associated with the plasma membrane. Interestingly however, several studies provide evidence showing that a larger fraction of total cellular GPER is localized in intracellular compartments. Revankar et al. used fluorescent E2 derivatives (E2-Alexas) to visualize the extra- and intracellular binding properties of GPER in COS-7 (monkey kidney fibroblast) cells. Surprisingly, the confocal images revealed that E2-Alexas failed to label the plasma membrane but predominantly bound to endoplasmic reticulum (31). In addition, E2-Alexas- or antibody-stained GPER is also colocalized in the Golgi apparatus and nuclear membrane in GPER expressing cancer cell lines (31). Similarly, the predominant intracellular staining pattern of GPER was also observed in human umbilical vein endothelial cells (74), vascular smooth muscle cells (74), and pancreatic islet cells $(75,76)$. Intriguingly, fluorescent microscopy and western blotting evidenced that GPER was present in mitochondria in undifferentiated $\mathrm{C} 2 \mathrm{C} 12$ myoblasts, but was found in cytoplasm in differentiated $\mathrm{C} 2 \mathrm{C} 12$ myotubes that modulates E2 actions (77). However, some other studies reported that GPER is mainly localized to the plasma membrane of uterine epithelia (78), myometrium (79), renal epithelia (80-82), and hippocampal neurons $(73,83)$, though an intracellular expression of GPER has also been reported in neurons (60). Therefore, the cellular distribution of GPER apparently varies depending on species, tissue, and cell types. Interestingly, several studies indicated that GPER is activated intracellularly, which then diffuses across cell membranes and initiates cellular signaling $(31,84,85)$. These results indicate that GPER is an atypical GPCR, and its intracellular location may dynamically change in response to specific environmental cues and also could be tissue-dependent. Thus, a role for GPER as a plasma membrane-based ER is still controversial, and the exact mechanism by which GPER acts in response to E2 remains elusive.

\section{GPER Ligands}

As discussed above, studies utilizing E2-Alexa or a fluorescent derivative of E2 demonstrated intracellular localizations of GPER $(31,86)$. Measurement of steroid binding to membraneassociated receptors is challenging because of the lipophilic nature of steroids and relatively low levels of membrane proteins that cause high background binding. Nevertheless, results from ligand binding assays demonstrated that GPER is a specific receptor for E2 with estimated binding affinities of 3-6nM $(30,31)$, which is however much lower as compared with its binding affinities for classical ERs that are in the range of 0.1-1.0 nM (87).

In addition to E2, compounds with estrogenic activity can be found in a large variety of natural sources such as plants (e.g., soy) and fungi (88). With the rapid development of synthetic estrogenic substances, it is not surprising that a large number of estrogenic compounds have been shown to interact with GPER. Tamoxifen, for instance, is a well-known selective ER modulator and found to act as a GPER agonist $(31,89)$. Interestingly, 
stimulation with 4-hydroxytamoxifen, the active metabolite of tamoxifen, failed to activate PI3K in ER $\alpha$ positive cells but did activate PI3K in GPER expressing cells (86). Another widely used selective $E R \alpha / \beta$ antagonist, ICI182,780 (ICI), was also shown to bind to GPER (30) and activate this receptor (90). In GPER-transfected MDA-MB-231 breast cancer cells (ER $\alpha$ deficient), ICI can activate ERK1/2 (90), confirming its effect as a GPER agonist. Consistently, another recent study demonstrated that raloxifene, a selective ER modulator, also elicited cellular response via GPER in ER $\alpha$-deficient endometrial carcinoma Hec50 cells (91). In addition, numerous synthetic estrogenic compounds have been shown to bind and/or activate GPER, including zearalonone, non-phenol, kepone, $\mathrm{p}, \mathrm{p}^{\prime}$-DDT, o, $\mathrm{p}^{\prime}$ DDE, 2, 2', 5', -PCB-4-OH (92), and bisphenol A $(93,94)$. Finally, several lines of research have demonstrated the agonistic actions of some plant-derived polyphenolic compounds toward GPER, including genistein $(40,92,95,96)$, quercetin (40), equol (97), resveratrol (98), oleuropein, hydroxytyrosol (99), and daidzein (100). However, it should be noted that the results from these studies were obtained exclusively from in-vitro-based assays using cancer cells or clonal cells with artificially overexpressed GPER, and whether and how they exert estrogenic effects as well as the target tissue in vivo are still unknown. Hence advancing the field of GPER research using these estrogenic compounds is fraught with complications. Fortunately, a highly selective GPER agonist, G-1, was synthesized in 2006 (101) and further studies of GPER action are greatly facilitated by this compound.

G-1 showed high binding affinity for GPER $(\mathrm{Kd}=10 \mathrm{nM})$ without binding to $\mathrm{ER} \alpha / \beta$ at concentrations as high as $10 \mu \mathrm{M}$ (102). Three years later, a subsequent study identified a highly selective GPER antagonist, G15, with a similar structure as G-1 but lacking the ethanone moiety (103), which displayed a minimal binding to $\mathrm{ER} \alpha / \beta(\mathrm{Kd}>10 \mu \mathrm{M})$ (104). Another GPER specific antagonist G36 was generated to restore the steric bulk of G-1 and the ER counter selectivity (102). These selective modulators of GPER have been used in over 200 studies to evaluate GPER actions in a variety of cellular and animal models. More recently, a first peptide GPER ligand corresponding to part of the hinge region/AF2 domain of the human $\mathrm{ER} \alpha$ was identified, which acts as an inverse agonist of GPER to suppress mitogenic signaling and inhibit breast cancer cell growth $(105,106)$. In addition, two novel GPER specific agonists, GPER-L1 and GPER-L2, were synthesized in 2012 with binding affinities of $\sim 100 \mathrm{nM}$ (107). The same year, a synthetic molecule, named as MIBE, was reported to bind and block both ER $\alpha$ and GPER activity in breast cancer cells (108). Recently, a small molecule with high binding selectivity to $\mathrm{ER} \alpha / \beta$ over GPER, termed AB-1, was generated, which may further aid distinguishing the roles of $E R \alpha / \beta$ and GPER in E2 signaling (109). Intriguingly, the widely used ER $\alpha$ specific agonist, propyl pyrazole triol (PPT), has been reported to act as GPER agonist at concentrations as low as $10-100 \mathrm{nM}$. On the contrary, the ER $\beta$ specific agonist, diarylpropionitrile (DPN), had no effect on GPER at concentrations up to $10 \mu \mathrm{M}$ (91). Therefore, the results from studies regarding the use of these compounds aimed at modulating ER actions should be interpreted carefully with respect to the concentrations of these compounds.

\section{GPER IN HEALTH AND DISEASE}

With the increasing spectrum of research on GPER in vitro, many critical questions remain: what is the physiological role of GPER? Does GPER really serve as a GPER and act independently or collaborate with the classical ERs? Will drugs targeting GPER be more effective than those targeting ER $\alpha / \beta$ for treatment of disease? Although GPER was officially named by the International Union of Basic and Clinical Pharmacology in 2007 (43), deciphering the physiology role(s) of GPER as a novel ER in health and disease remains challenging, which is due to the complex nature of E2-initiated cellular events that involve multiple receptors, various cellular signaling cascades, direct or indirect binding of the E2-ER complex to DNA, and regulation of gene expression. While these aspects are beyond the scope of this review, various mechanisms of E2 signaling are summarized in Figure 1. The readers can refer to other review papers on this topic [see $(90,110,111)$ for more detailed information]. In the following section, recent studies regarding the physiological roles of GPER in different tissues and disease are discussed.

\section{GPER in Reproductive System}

Since GPER is believed to be an ER, its action in the reproductive system attracted considerable attention. Early studies investigating the action of GPER were performed in various cancer cells derived primarily from reproductive tissues, including breast $(30,36,36)$, ovary $(112-114)$, endometrium $(89,115,116)$, testis $(117,118)$, prostate $(119)$, as well as thyroid tissues $(95,120)$. Since GPER was first identified and cloned in breast cancer cells, much early research has focused on exploring the role of GPER in various types of cancer, which has been reviewed thoroughly elsewhere (121-123) and will be briefly discussed in this space. For instance, Upon stimulation with E2, estrogenic compounds (e.g., genistein, hydroxytamoxifen) or selective GPER agonist G-1, GPER enhanced cancer cell proliferation in the classical-ER-negative breast cancer cells (30) and in the thyroid (95), endometrial (89), and ovarian cancer cells (113), suggesting that GPER may contribute to E2-induced cancer growth. Research by De Francesco., el al. provides novel insight into the mechanism by which activation of GPER triggers cancer cell proliferation (124). Specifically, their research demonstrated that E2 and GPER specific agonist G-1 upregulated HIF1 $\alpha$-dependent vascular endothelial growth factor expression in ER-negative breast cancer cells and cancerassociated fibroblasts, which led to angiogenesis and breast cancer progression as shown in a mouse xenograft model of breast cancer. Interestingly, It was shown that GPER specific agonist G-1 suppressed SKOV-3 and OVCAR-3 cell proliferation and activated caspase-dependent cell apoptosis, indicating that GPER may act as a tumor suppresser for ovarian cancer (125). In line with this finding, several reports also discovered such contrary effects of GPER in reproductive cell lines. Activation of GPER by E2 or G-1 suppressed human bladder urothelial cell 


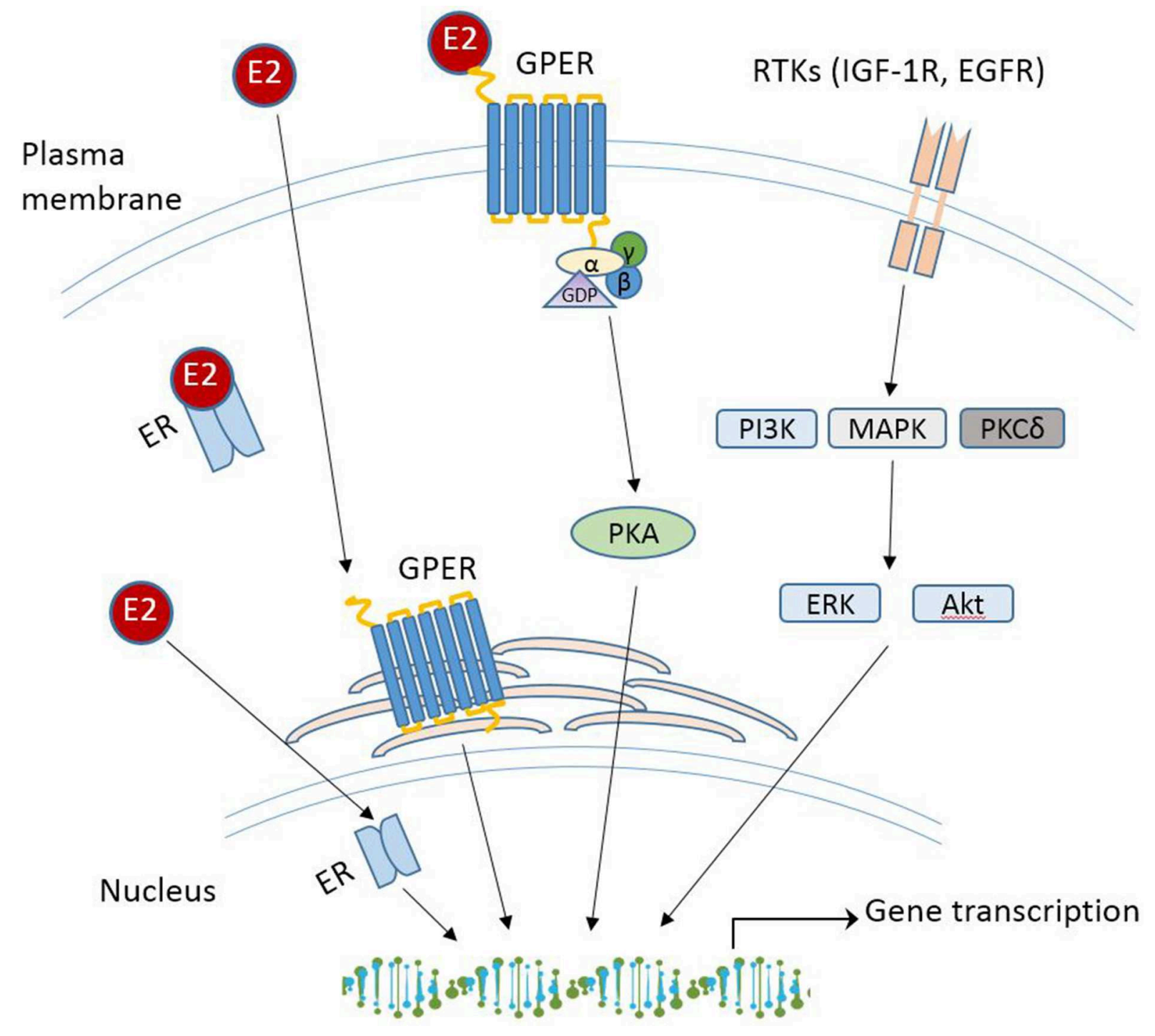

FIGURE 1 | Schematic overview of E2 signaling pathways. RTK, receptor tyrosine kinases; IGF-1R, insulin-like growth factor 1 receptor; EGFR, epidermal growth factor receptor; PI3K, phosphoinositide 3-kinase; MAPK, mitogen-activated protein kinases; PKC 8 , protein kinase C-delta; Akt, protein kinase B.

proliferation via down-regulating the activation of protein-1 (AP1) (126), which is one of the major regulators of cell proliferation (127). Similarly, in the classical ER negative human breast cancer cell lines SkBr3 and MDA-MB-231, activation of GPER by G1 inhibited cell proliferation and induced G2 cell-cycle arrest in vitro and suppressed ER negative breast cancer growth in vivo (128). In ovarian-like granulosa tumor cells, E2 activates GPER-protein kinase C signaling, which then phosphorylates forkhead transcription factor 2 to promote cell apoptosis (129). In human, activation of GPER by G-1 enhanced contractile responses to oxytocin in the myometrium during labor (79). In addition, GPER together with ER $\alpha$ regulates the proliferative and/or apoptotic pathways involved in spermatogenesis via the EGFR/ERK/c-jun pathway in male rodent reproductive development $(130,131)$. However, the physiological relevance of these in vitro findings are unknown. Actually, in contrast to these in vitro findings, activation $(101,132)$ or deletion of GPER $(57,58)$ displayed no effect on the development of reproductive organs in mice, which is in clear contrast to the established phenotype of these animals lacking ER $\alpha$ or E2. This result suggests that GPER may be either not endogenously activated by E2 or not involved in mediating estrogenic actions of E2 in reproductive organs. Interestingly, studies from ovariectomized mice indicated that activation of GPER inhibited E2-induced uterine epithelial cell proliferation, which was associated with the reduced E2-stimulated ER $\alpha$ phosphorylation (78), Therefore, GPER inhibition of E2-stimulated cell proliferation may be mediated via suppressing the phosphorylation of $\mathrm{ER} \alpha$, which is important for various E2-stimulated transcriptional events (54), suggesting a possible "yin-yang" relationship between 
these two receptor. These findings demonstrate the complex roles of GPER in reproductive system and further investigation is needed.

\section{GPER in Cardiovascular System}

Increasing evidence shows that GPER exerts cardioprotective effects. In mouse models, It was shown that global deletion of GPER increased blood pressures (57), atherosclerosis progression and systemic inflammation (74). GPER also plays a direct cardioprotective role, as mice with a cardiomyocyte-specific deletion of GPER displayed abnormal cardiac structure and impaired systolic and diastolic function (133). GPER may mediate a direct vasodilatory effect of E2 in vasculature. As a selective antagonist of the classic ER $\alpha / \beta$, ICI exhibited agonistic action on GPER and promoted the dilation of coronary artery in porcine (134). Interestingly, acute infusion of GPER selective agonist G-1 decreased blood pressure in male rats, while longterm injection of G-1 decreased mean arterial pressure in the hypertensive ovariectomized female rats, suggesting that activation of GPER potentially protects E2-insufficient females from hypertension (135). In line with the results from using animal models, stimulation by G-1 dilated human internal mammary arteries and notably, the relaxant effects of G-1 were more potent than that of $\mathrm{E} 2$ in precontracted human aorta and carotid artery (136). The exact mechanism for blood pressure-lowering action of GPER is not clear. Studies from GPER knockout mice suggest that GPER can directly stimulate nitric oxide (NO) production from endothelial cells (ECs) and subsequent vessel dilatation (137, 138). Indeed, treatment with GPER selective antagonist G36 suppressed E2induecd NO release in human ECs, whereas activation of GPER with G-1 promoted endothelial NO synthase phosphorylation (138), suggesting that GPER is at least partially responsible for NO-mediated vasodilatory action of E2. Another study demonstrated that activation of GPER inhibited endothelintriggered vasoconstriction via reducing vascular smooth muscle cell Ca (2+) sensitivity (139). Further, GPER was shown to protect against angiotensin (Ang) II-induced hypertension through suppressing NADPH oxidase 4-dependent oxidative stress via activation of cAMP signaling pathway (140), suggesting that this receptor also exerts an antioxidant role. Therefore, GPER could potentially be a target for developing strategy to promote cardiovascular health.

\section{GPER in Nervous System}

Estrogen has many beneficial effects in the brain, which include improving cognitive performance (141), opposing the early occurring hippocampal damage (142), increasing neuronal connectivity (143), and preventing or slowing age-related cognitive decline (144). Although these protective effects of E2 are largely attributed to the classical $E R \alpha / \beta$, increasing evidence demonstrates that GPER also plays potential role(s) in E2-mediated neurological functions. As stated before, GPER is expressed throughout the central and peripheral nervous system of male and female rodents and humans (49). Acute administration of E2 or GPER selective agonists STX or G-1, improved neuron survival rate by $40-45 \%$ compared to control in ovariectomized female rats (145). In contrast, G-1 promoted apoptosis of rat embryo cortical astrocytes exposed to oxygen and glucose deprivation, whereas the addition of the GPER antagonist G-15 suppressed this effect, suggesting a direct impact of GPER on the viability of cortical astrocytes (146). Interestingly, administration of G-1 counteracted iron- and ovariectomyinduced memory impairments in female rats (147). Therefore, GPER could be a novel target in treatment of neurodegenerative diseases, such as memory disorders, Alzheimer's disease and ischemic stroke. Although the results from limited studies using selective chemicals of GPER consistently demonstrate a neuronal effect of GPER, it remains to be determined whether GPER truly acts as an E2 receptor. As reported, infusion of G-1 or E2 promoted memory function in ovariectomized female mice, but G-1 activated the c-Jun N-terminal kinase while E2 stimulated ERK1/2. In addition, G15 failed to block the activation of ERK1/2 induced by E2, but infusion of G15 to the dorsal hippocampus impaired memory formation and object recognition (148). These data suggest that the benefits of hippocampal GPER on memory function is not mediated by E2. Thus, the role and precise sites in neurons responsible for GPER action need to be elucidated, which may be achieved by using tissue-specific knockout animal models.

\section{GPER and Glucose Metabolism}

While the classic ERs have been known to play a role in mediating E2 effects on glucose metabolism and metabolic diseases, the metabolic action of GPER remains to be determined. The generation of GPER knockout (GPRKO) mice facilitates our understanding of the physiology role of GPER. Martensson et al. showed for the first time that GPRKO female mice displayed hyperglycemia, impaired glucose tolerance, and reduced body weight and bone growth, whereas GPRKO male mice were metabolically normal (57), thus demonstrating a genderdependent effects of GPER on glucose homeostasis and animal growth. The potential anti-diabetic effect of GPER was revealed from studying the $E R \alpha / \beta$ double knockout (DKO) mice treated with streptozotocin (STZ) (149), in which $E 2 / E R \alpha / \beta$ signaling was removed, thereby allowing to determine only GPERmediated action of E2. The results indicated that ovariectomized $\mathrm{ER} \alpha / \beta$ DKO mice were more susceptible to STZ-induced islet apoptosis and diabetes as compared with sham-operated ER $\alpha / \beta$ DKO mice, but the STZ-induced islet apoptosis and diabetes in ovariectomized $\mathrm{ER} \alpha / \beta$ DKO mice were attenuated by $\mathrm{E} 2$ replacement therapy (149), suggesting that E2/GPER signaling is protective against STZ-induced insulin deficient diabetes. Indeed, the authors further demonstrated that female GPRKO mice were predisposed to insulin-deficient diabetes due to increased $\beta$-cell apoptosis. In accordance with this in vivo result, GPER agonist G-1 directly protected mouse and human islets against oxidative stress-induced apoptosis, and E2 still promoted pancreatic $\beta$ cell survival in ER $\alpha / \beta$ DKO mice exposed to STZ (150). Taken together, these results showed that in the absence of the classical $\mathrm{ER} \alpha / \beta$, E2 may signal through GPER to protect against STZinduced islet apoptosis. Consistently, data from several other studies showed that deletion of GPER resulted in a reduced insulin secretion from pancreas, suggesting that GPER indeed 
plays a role in maintaining metabolic functions via regulating insulin secretion in mice $(149,151,152)$. Furthermore, the protective effect of $\mathrm{E} 2$ on pancreatic $\beta$-cells can be mimicked by GPER agonist, genistein (153). Interestingly, we recently found that deletion of GPER protected female mice from high-fat diet (HFD)-induced obesity and hyperglycemia (154). After 15 weeks of HFD feeding, their blood glucose levels gradually diverged with GPRKO displaying significantly lower fasting and nonfasting blood glucose levels as compared with those in WT while their insulin sensitivity was not different. The reason for these discrepancies are not clear. It should be noted that our study used GPER mice in 129 background in contrast to C57BL/6 GPER mice as used in other studies. Other factors, such as the genetic knockdown or knockout strategy, the breeding strategy, and the environment can have unexpected influence on the phenotypes as well. Of the note, certain maternal and/or experimental diets contain significant amount of phytoestrogens (i.e., soy protein or alfalfa meal) (155), which could modulate the estrogenic activity and therefore could profoundly alter the related outcome of a study given the well-documented various effects of dietary phytoestrogens in rodent models $(156,157)$.

\section{GPER and Obesity}

While the classical ERs have been well-investigated regarding their roles in mediating E2 effects on fat metabolism and metabolic diseases, little is known about metabolic action of GPER as well as the possible complex interactions among the three ERs in different cell types. E2 and STX, a synthesized nonsteroidal compound acting as a GPER selective agonist (158), rapidly attenuated the baclofen response in hypothalamic arcuate POMC neurons in WT, ER $\alpha \mathrm{KO}, \mathrm{ER} \beta \mathrm{KO}$, and $\mathrm{ER} \alpha / \beta$ DKO mice, and prevented excessive body weight gain in ovariectomized guinea pigs, suggesting a potential role of GPER in energy metabolism in females (159). Multiple studies have investigated the role of GPER in regulating body weight and fat deposits. The first such study reported an increase in body weight and visceral adiposity in both male and female GPRKO mice as compared with those in WT mice (151). In addition, Davis et al. reported similar observations that $\mathrm{KO}$ mice were heavier than the WT littermates fed a standard chow diet (STD), although this difference between female mice occurred 5 weeks later as compared to male mice (51). However, others found no significant effect of GPER on body weight of both female and male mice (52). Data from a recent study showed an increased body weights in both male and female GPRKO mice caused by increased fat mass with enlarged adipocytes when fed a phytoestrogen free low fat diet (51). However, Martensson et al. reported contrary results that female GPRKO mice exhibited slightly lower body weights as compared with WT, whereas no such differences were observed in male GPRKO mice (57). The reasons for these disparate results are not clear. However, these studies were not designed for investigating the roles of GPER in obesity development. As female mice in these studies were used at their young ages and fed a STD, they remain lean without apparent metabolic abnormalities, which therefore are not sufficient to reveal the role of GPER in obesity development that is typically caused by high calorie intake.
We recently performed relatively long-term study with detailed analyses of body weight and body composition of female GPRKO mice either maintained on a STD or exposed to a phytoestrogen-free HFD (154). There were no differences in their body weight, fat mass, and all other measured metabolic phenotypes between WT and GPRKO either male or female mice on a STD. However, after 23 weeks of HFD feeding, female GPRKO mice gained $61 \%$ of their starting body weight while WT female mice increased by $85 \%$ with no difference in energy intake between two groups. At 20 weeks, the fat mass of WT was 1.8fold of that in GPRKO mice with only slightly higher lean body mass in GPRKO animals, suggesting that the difference in body weight between GPRKO and WT female mice was primarily due to their fat mass difference. Interestingly, no such differences in metabolic phenotypes were observed between WT and GPRKO male mice fed a HFD. In addition, the inguinal, gonadal, and perirenal fat pads from GPRKO mice weighted less than those in WT female mice, while the pancreas from GPRKO female mice was slightly heavier than WT mice. All the other measured organs weights are similar, suggesting the reduced fat mass in GPRKO female mice was not due to decreased body growth. Our H\&E staining of fat sections revealed that GPRKO female mice had smaller adipocytes as compared to WT female mice fed a HFD. While the reasons for these disparities with respect to GPER modulation of body weight gain from past studies are not clear, which could be due to the different methods generating the transgenic animals as reviewed (71), and the variations of the diet compositions, duration, and environment, but overall they indicate that GPER might play a role in regulating lipid metabolism and controlling adiposity.

While how exactly GPER regulates lipid metabolism is still unclear, it was recently shown that that the effect of GPER on fat mass in HFD-fed female mice was not due to a secondary action by which its deletion altered circulating E2 levels or expression of $\mathrm{ER} \alpha$ (154), which is believed to play a major role in mediating estrogenic effects on energy homeostasis (160). Both human and rodent white adipose tissue expresses ER $\alpha$, ER $\beta$, and GPER, suggesting that E2 signaling could occur through both ERs and GPER. Interestingly, it was reported that GPER and ER $\alpha$ inhibit each other's actions in several types of cells $(78,161,162)$. In mice, GPER activation inhibits ER $\alpha$-dependent uterine growth induced by E2 (78). These data suggest that there could also be a "yin-yang" relationship between GPER and ER $\alpha$ in adipose tissue that balances energy metabolism in response to E2. In that regard, activation of $\mathrm{ER} \alpha$ by $\mathrm{E} 2$ inhibits adiposity, whereas activation of GPER might promote obesity, an intriguing concept that worth investigation.

\section{EVIDENCE OF E2-INDEPENDENT EFFECTS OF GPER}

While data from a large body of literature suggest that GPER appears to mediate E2-triggered several intracellular signaling pathways, this evidence was primarily obtained from in vitro studies in which cultured cells were often either overexpressed with GPER or absent of endogenous $E R \alpha / \beta$ and typically exposed 
to well-above physiological doses of E2. As aforementioned, the estimated binding affinities of E2 to GPER $(3-6 \mathrm{nM})(30,31)$ are considerably higher as compared with its binding affinities for classical ERs (0.1-1 nM) (87). This raises an interesting question as to whether GPER plays a significant role in mediating various E2 effects in vivo, given that circulating E2 levels in young female rodents are only about 7.3-734.2 pM (163-165), depending on the stage of estrous cycle. Indeed, conflicting results regarding the GPER-mediated signaling events in response to E2 continue to emerge, which warrant further investigations as to whether GPER plays a physiological role as an GPER in vivo. Knockdown of GPER in MCF-7 cells expressing ERs and GPER had no impacts on E2-induced cAMP production (166). Others demonstrated that transient expression of GPER in MCF-7 cells resulted in a reduction of cell growth in the absence of E2 (167). Based on these results, GPER may not signal in response to the stimulation of E2 at physiologically relevant levels. Intriguingly, the existence of membrane ERs (mERs) (168-171), though with a limited amount at about $3-10 \%$ of the classical nuclear ERs $(29,166)$, further complicated the rapid non-genomic signaling events mediated by E2. Interestingly, G-1 was shown to induce the phosphorylation of ERK1/2 in GPER-negative HEK293 cells stably transfected with a novel membrane associated $\mathrm{ER} \alpha, \mathrm{ER} \alpha-36$ (172), a variant of human ER $\alpha-66$ (168). Moreover, knockdown of ER $\alpha-36$ in MDA-MB-231 and SKBr3 cells suppressed the phosphorylation of ERK1/2 and intracellular calcium mobilization stimulated by G-1, suggesting that G-1 also recognizes ER $\alpha-36$, and therefore it may not be specific for GPER. The use of ICI, an ER $\alpha$ antagonist but GPER agonist, and GPER antagonist G-15, in the mouse hippocampal cell lines mHippoE-14 and mHippoE-18 demonstrated that acute E2 treatment protected hippocampal cells from glutamate-induced neurotoxicity and the protective action requires both $\operatorname{mER} \alpha$ and GPER (173). In ovariectomized female mice, it was shown that infusion of E2 into the dorsal hippocampus activated $\mathrm{ER} \alpha$ and $\mathrm{ER} \beta$, leading to ERK1/2 signaling and improved object recognition and spatial memory. However, infusion of G-1 but not E2 activated GPER, which triggered a different cell-signaling mechanism to facilitate hippocampal memory in female mice (148). These results suggest that GPER in the dorsal hippocampus might not act as an ER. In GPER overexpressed COS-7 and CHO cells, E2 only showed specific saturated binding to $\mathrm{ER} \alpha$, but not to GPER (132). Consistently, in primary endothelial cells from $E R \alpha / \beta$ DKO mice, E2 failed to specifically bind to GPER and activate

\section{REFERENCES}

1. Korach KS. Insights from the study of animals lacking functional estrogen receptor. Science. (1994) 266:1524-7.

2. Hess RA. Estrogen in the adult male reproductive tract: a review. Reprod Biol Endocrinol. (2003) 1:52. doi: 10.1186/1477-7827$1-52$

3. Suzuki S, Brown CM, Wise PM. Mechanisms of neuroprotection by estrogen. Endocrine. (2006) 29:209-15. doi: 10.1385/Endo:2 9:2:209

4. Grossman CJ. Regulation of the immune system by sex steroids. Endocr Rev. (1984) 5:435-55. doi: 10.1210/edrv-5-3-435
cAMP, ERK1/2, or PI3K signaling as observed in clonal cancer cells (166).

The reason for these disparate results on the role of GPER in E2 signaling is unclear. Many of these studies were obtained using clonal cell-based experiments, in which cells were manipulated with overexpression of GPER, which may result in ectopic expression of GPER in the cells. Even using the cells that endogenously express GPER, cellular experiment results cannot recapitulate E2 functions in whole body. Taken together, it remains to be determined whether GPER functions as a specific $\mathrm{E} 2$ receptor that mediates endogenous $\mathrm{E} 2$ effects in vivo.

\section{CONCLUDING REMARKS}

GPER is an atypical GPCR and has been named as a new ER. While $E R \alpha / \beta$ have been well-investigated regarding their roles in mediating E2 effects in health and disease, the physiological and/or pathological roles of GPER remain to be determined. The pace of research into the functions of GPER has been accelerating over the past decade with the generation of GPER transgenic mice as well as its selective chemical ligands, which are powerful tools to investigate the physiological and/or pathological role(s) of GPER. Although the results from in vitro studies suggest that E2 could activate to trigger various intracellular signaling pathways, and data from animal studies do not exclude GPER as an ER in mediating estrogenic responses, convincing evidence that E2 acts through GPER to elicit significant physiological events in vivo is still lacking $(58,132,174)$. While the major physiological function of GPER is likely not for promoting reproductive tissue development, increasing evidence suggest that GPER plays a role in body weight regulation and metabolism. However, the clear metabolic effects of GPER and the role of E2 plays in this context need further investigation. In addition, whether GPER counteracts $\mathrm{ER} \alpha$ in energy metabolism is an intriguing question that needs to be addressed in future research. Finally, future research should also be aimed at understanding GPER biology in humans, which has been seldom investigated.

\section{AUTHOR CONTRIBUTIONS}

All authors made substantial contributions to the conception and design of this review paper, drafted the manuscript and revised it critically for important intellectual content, and approval it for publication.

5. Cutolo M, Sulli A, Capellino S, Villaggio B, Montagna P, Seriolo B, et al. Sex hormones influence on the immune system: basic and clinical aspects in autoimmunity. Lupus. (2004) 13:635-8. doi: 10.1191/0961203304lu1094oa

6. Vidal O, Lindberg MK, Hollberg K, Baylink DJ, Andersson G, Lubahn $\mathrm{DB}$, et al. Estrogen receptor specificity in the regulation of skeletal growth and maturation in male mice. Proc Natl Acad Sci USA. (2000) 97:5474-9. doi: 10.1073/pnas.97.10.5474

7. Turner RT, Riggs BL, Spelsberg TC. Skeletal effects of estrogen. Endocr Rev. (1994) 15:275-300. doi: 10.1210/edrv-15-3-275

8. Mauvais-Jarvis F, Clegg DJ, Hevener AL. The role of estrogens in control of energy balance and glucose homeostasis. Endocr Rev. (2013) 34:309-38. doi: $10.1210 /$ er.2012-1055 
9. Brown LM, Clegg DJ. Central effects of estradiol in the regulation of food intake, body weight, and adiposity. J Steroid Biochem Mol Biol. (2010) 122:65-73. doi: 10.1016/j.jsbmb.2009.12.005

10. D’Eon TM, Souza SC, Aronovitz M, Obin MS, Fried SK, Greenberg AS. Estrogen regulation of adiposity and fuel partitioning. Evidence of genomic and non-genomic regulation of lipogenic and oxidative pathways. J Biol Chem. (2005) 280:35983-91. doi: 10.1074/jbc.M507339200

11. Brown LM, Gent L, Davis K, Clegg DJ. Metabolic impact of sex hormones on obesity. Brain Res. (2010) 1350:77-85. doi: 10.1016/j.brainres.2010.04.056

12. Monteiro R, Teixeira D, Calhau C. Estrogen signaling in metabolic inflammation. Mediators Inflamm. (2014) 2014:615917. doi: $10.1155 / 2014 / 615917$

13. Straub RH. The complex role of estrogens in inflammation. Endocr Rev. (2007) 28:521-74. doi: 10.1210/er.2007-0001

14. Edwards DP. Regulation of signal transduction pathways by estrogen and progesterone. Annu Rev Physiol. (2005) 67:335-76. doi: 10.1146/annurev.physiol.67.040403.120151

15. Prossnitz ER, Arterburn JB, Smith HO, Oprea TI, Sklar LA, Hathaway HJ. Estrogen signaling through the transmembrane G proteincoupled receptor GPR30. Ann Rev Physiol. (2008) 70:165-190. doi: 10.1146/annurev.physiol.70.113006

16. Jensen EV, Desombre ER. Estrogen-receptor interaction. Science. (1973) 182:126-34. doi: 10.1126/science.182.4108.126

17. Talwar GP, Segal SJ, Evans A, Davidson OW. The binding of estradiol in the uterus: a mechanism for depression of RNA synthesis. Proc Natl Acad Sci USA. (1964) 52:1059-66.

18. Soloff MS, Szego CM. Purification of estradiol receptor from rat uterus and blockade of its estrogen-binding function by specific antibody. Biochem Biophys Res Commun. (1969) 34:141-7.

19. Lubahn DB, Moyer JS, Golding TS, Couse JF, Korach KS, Smithies O. Alteration of reproductive function but not prenatal sexual development after insertional disruption of the mouse estrogen receptor gene. Proc Natl Acad Sci USA. (1993) 90:11162-6.

20. Kuiper GG, Enmark E, Pelto-Huikko M, Nilsson S, Gustafsson JA. Cloning of a novel receptor expressed in rat prostate and ovary. Proc Natl Acad Sci USA. (1996) 93:5925-30.

21. Ge X, Guo RX, Qiao YH, Zhang YC, Lei J, Wang XY, et al. The G proteincoupled receptor GPR30 mediates the nontranscriptional effect of estrogen on the activation of PI3K/Akt pathway in endometrial cancer cells. Intl J Gynecological Cancer. (2013) 23:52-59. doi: 10.1097/IGC.0b013e31827912b8

22. Kelly MJ, Lagrange AH. Nontranscriptional effects of estradiol in neuropeptide neurons. Curr Opinion Endocrinol Diabetes Obesity. (1998) 5:66.

23. Improta-Brears T, Whorton AR, Codazzi F, York JD, Meyer T, McDonnell DP. Estrogen-induced activation of mitogen-activated protein kinase requires mobilization of intracellular calcium. Proc Natl Acad Sci USA. (1999) 96:4686-91.

24. Aronica SM, Kraus WL, Katzenellenbogen BS. Estrogen action via the cAMP signaling pathway: stimulation of adenylate cyclase and cAMP-regulated gene transcription. Proc Natl Acad Sci USA. (1994) 91:8517-21.

25. Migliaccio A, DiDomenico M, Castoria GA, deFalco, Bontempo P, Nola E, et al. Tyrosine kinase/p21(ras)/MAP-kinase pathway activation by estradiolreceptor complex in MCF-7 cells. Embo J. (1996) 15:1292-300.

26. Endoh H, Sasaki H, Maruyama K, Takeyama K, Waga I, Shimizu T, et al. Rapid activation of MAP kinase by estrogen in the bone cell line. Biochem Biophys Res Commun. (1997) 235:99-102.

27. Watters JJ, Campbell JS, Cunningham MJ, Krebs EG, Dorsa DM. Rapid membrane effects of steroids in neuroblastoma cells: effects of estrogen on mitogen activated protein kinase signalling cascade and cfos immediate early gene transcription. Endocrinology. (1997) 138:4030-3. doi: 10.1210/endo.138.9.5489

28. Moss RL, Gu Q, Wong M. Estrogen: nontranscriptional signaling pathway. Recent Prog Horm Res. (1997) 52:33-68; discussion 68-9.

29. Razandi M, Pedram A, Greene GL, Levin ER. Cell membrane and nuclear estrogen receptors (ERs) originate from a single transcript: studies of $\mathrm{ER} \alpha$ and ER $\beta$ expressed in Chinese hamster ovary cells. Mol Endocrinol. (1999) 13:307-19.
30. Thomas P, Pang Y, Filardo EJ, Dong J Identity of an estrogen membrane receptor coupled to a G protein in human breast cancer cells. Endocrinology. (2005) 146:624-32. doi: 10.1210/en.2004-1064

31. Revankar CM, Cimino DF, Sklar LA, Arterburn JB, Prossnitz ER. A transmembrane intracellular estrogen receptor mediates rapid cell signaling. Science. (2005) 307:1625-30. doi: 10.1126/science.1106943

32. Szego CM, Davis JS. Adenosine 3',5'-monophosphate in rat uterus acute elevation by estrogen. Proc Natl Acad Sci USA. (1967) 58:1711. doi: 10.1073/pnas.58.4.1711

33. Pietras RJ, Szego CM. Endometrial cell calcium and estrogen action. Nature. (1975) 253:357-9. doi: 10.1038/253357a0

34. Fu XD, Simoncini T. Extra-nuclear signaling of estrogen receptors. Iubmb Life. (2008) 60:502-10. doi: 10.1002/iub.80

35. Levin ER. Plasma membrane estrogen receptors. Trends Endocrinol Metab. (2009) 20:477-82. doi: 10.1016/j.tem.2009.06.009

36. Carmeci C, Thompson DA, Ring HZ, Francke U, Weigel RJ. Identification of a gene (GPR30) with homology to the G-protein-coupled receptor superfamily associated with estrogen receptor expression in breast cancer. Genomics. (1997) 45:607-17. doi: 10.1006/geno.1997.4972

37. Owman C, Blay P, Nilsson C, Lolait SJ. Cloning of human cDNA encoding a novel heptahelix receptor expressed in Burkitt's lymphoma and widely distributed in brain and peripheral tissues. Biochem Biophys Res Commun. (1996) 228:285-92. doi: 10.1006/bbrc.1996.1654

38. Takada Y, Kato C, Kondo S, Korenaga R, Ando J. Cloning of cDNAs encoding $\mathrm{G}$ protein-coupled receptor expressed in human endothelial cells exposed to fluid shear stress. Biochem Biophys Res Commun. (1997) 240:737-41. doi: 10.1006/bbrc. 1997.7734

39. Feng Y, Gregor P. Cloning of a novel member of the G protein-coupled receptor family related to peptide receptors. Biochem Biophys Res Commun. (1997) 231:651-4. doi: 10.1006/bbrc.1997.6161

40. Maggiolini M, Vivacqua A, Fasanella G, Recchia AG, Sisci D, Pezzi V, et al. The G protein-coupled receptor GPR30 mediates c-fos up-regulation by 17beta-estradiol and phytoestrogens in breast cancer cells. J Biol Chem. (2004) 279:27008-16. doi: 10.1074/jbc.M403588200

41. Rae JM, Johnson MD. What does an orphan G-protein-coupled receptor have to do with estrogen? Breast Cancer Res. (2005) 7:243-4. doi: 10.1186/bcr1330

42. Hsieh YC, Yu HP, Frink M, Suzuki T, Choudhry MA, Schwacha $\mathrm{MG}$, et al. G protein-coupled receptor 30-dependent protein kinase a pathway is critical in nongenomic effects of estrogen in attenuating liver injury after trauma-hemorrhage. Am J Pathol. (2007) 170:1210-8. doi: 10.2353/ajpath.2007.060883

43. Alexander SP, Mathie A, Peters JA. Guide to receptors and channels (GRAC), 5th edition. Br J Pharmacol. (2011) 164:S1-324. doi: 10.1111/j.1476-381.2011.01649

44. Nilsson S, Gustafsson JA. Estrogen receptors: therapies targeted to receptor subtypes. Clin Pharmacol Ther. (2011) 89:44-55. doi: 10.1038/clpt.2010.226

45. Nilsson S, Makela S, Treuter E, Tujague M, Thomsen J, Andersson G, et al. Mechanisms of estrogen action. Physiol Rev. (2001) 81:1535-65. doi: 10.1152/physrev.2001.81.4.1535

46. Heldring N, Pike A, Andersson S, Matthews J, Cheng G, Hartman J, et al. Estrogen receptors: How do they signal and what are their targets. Physiological Rev. (2007) 87:905-31. doi: 10.1152/physrev.00026.2006

47. Filardo EJ, Thomas P. Minireview: G protein-coupled estrogen receptor1, GPER-1: its mechanism of action and role in female reproductive cancer, renal and vascular physiology. Endocrinology. (2012) 153:2953-62. doi: 10.1210/en.2012-1061

48. Sanden C, Broselid S, Cornmark L, Andersson K, Daszkiewicz-Nilsson J, Martensson UE, et al. Leeb-Lundberg: G protein-coupled estrogen receptor $1 / G$ protein-coupled receptor 30 localizes in the plasma membrane and traffics intracellularly on cytokeratin intermediate filaments. Mol Pharmacol. (2011) 79:400-10. doi: 10.1124/mol.110.069500

49. Olde BLMF. Leeb-Lundberg: GPR30/GPER1: searching for a role in estrogen physiology. Trends Endocrinol Metab. (2009) 20:409-16. doi: 10.1016/j.tem.2009.04.006

50. Bluher M. Importance of estrogen receptors in adipose tissue function. $\mathrm{Mol}$ Metab. (2013) 2:130-2. doi: 10.1016/j.molmet.2013.07.001 
51. Davis KE, Carstens EJ, Irani BG, Gent LM, Hahner LM, Clegg DJ. Sexually dimorphic role of $G$ protein-coupled estrogen receptor (GPER) in modulating energy homeostasis. Horm Behav. (2014) 66:196-207. doi: 10.1016/j.yhbeh.2014.02.004

52. Isensee J, Meoli L, Zazzu V, Nabzdyk C, Witt H, Soewarto D, et al. Expression pattern of G protein-coupled receptor 30 in LacZ reporter mice. Endocrinology. (2009) 150:1722-30. doi: 10.1210/en.2008-1488

53. Filardo EJ, Quinn JA, Frackelton AR Jr, Bland KI. Estrogen action via the G protein-coupled receptor, GPR30: stimulation of adenylyl cyclase and cAMP-mediated attenuation of the epidermal growth factor receptor-to-MAPK signaling axis. Mol Endocrinol. (2002) 16:70-84. doi: $10.1210 /$ mend.16.1.0758

54. Zhu L, Pollard JW. Estradiol-17 beta regulates mouse uterine epithelial cell proliferation through insulin-like growth factor 1 signaling. Proc Natl Acad Sci USA. (2007) 104:15847-51. doi: 10.1073/pnas.0705749104

55. Kvingedal AM, Smeland EB. A novel putative G-protein-coupled receptor expressed in lung, heart and lymphoid tissue. FEBS Lett. (1997) 407:59-62.

56. O’Dowd BF, Nguyen T, Marchese A, Cheng R, Lynch KR, Heng HH, et al. Discovery of three novel G-protein-coupled receptor genes. Genomics. (1998) 47:310-3. doi: 10.1006/geno.1998.5095

57. Martensson UE, Salehi SA, Windahl S, Gomez MF, Sward K, DaszkiewiczNilsson JA. Deletion of the G protein-coupled receptor 30 impairs glucose tolerance, reduces bone growth, increases blood pressure, and eliminates estradiol-stimulated insulin release in female mice. Endocrinology. (2009) 150:687-98. doi: 10.1210/en.2008-0623

58. Otto C, Fuchs I, Kauselmann G, Kern H, Zevnik B, Andreasen P, et al. GPR30 does not mediate estrogenic responses in reproductive organs in mice. Biol Reprod. (2009) 80:34-41. doi: 10.1095/biolreprod.108. 071175

59. Bonini JA, Anderson SM, Steiner DF. Molecular cloning and tissue expression of a novel orphan $G$ protein-coupled receptor from rat lung. Biochem Biophys Res Commun. (1997) 234:190-3.

60. Brailoiu E, Dun SL, Brailoiu GC, Mizuo K, Sklar LA, Oprea TI, et al. Distribution and characterization of estrogen receptor $\mathrm{G}$ protein-coupled receptor 30 in the rat central nervous system. J Endocrinol. (2007) 193:31121. doi: 10.1677/JOE-07-0017

61. Dun SL, Brailoiu GC, Gao X, Brailoiu E, Arterburn JB, Prossnitz ER, et al. Expression of estrogen receptor GPR30 in the rat spinal cord and in autonomic and sensory ganglia. J Neurosci Res. (2009) 87:1610-9. doi: $10.1002 /$ jnr.21980

62. Hazell GG, Yao ST, Roper JA, Prossnitz ER, O'Carroll AM, Lolait SJ. Localisation of GPR30, a novel G protein-coupled oestrogen receptor, suggests multiple functions in rodent brain and peripheral tissues. $J$ Endocrinol. (2009) 202:223-36. doi: 10.1677/JOE-09-0066

63. Hugo ER, Brandebourg TD, Woo JG, Loftus J, Alexander JW, Ben-Jonathan N. Bisphenol A at environmentally relevant doses inhibits adiponectin release from human adipose tissue explants and adipocytes. Environ Health Perspectives. (2008) 116:1642-7. doi: 10.1289/ehp.11537

64. Shi HF, Kumar SP, Liu X. G protein-coupled estrogen receptor in energy homeostasis and obesity pathogenesis. GPCR Energy Hom Obesity Path. (2013) 114:193-250. doi: 10.1016/B978-0-12-386933-3.00006-6

65. Pollanen E, Sipila S, Alen M, Ronkainen PH, Ankarberg-Lindgren C, Puolakka J, et al. Differential influence of peripheral and systemic sex steroids on skeletal muscle quality in pre- and postmenopausal women. Aging Cell. (2011) 10:650-60. doi: 10.1111/j.1474-9726.2011.00701.x

66. Baltgalvis KA, Greising SM, Warren GL, Lowe DA. Estrogen regulates estrogen receptors and antioxidant gene expression in mouse skeletal muscle. PLoS ONE. (2010) 5:e10164. doi: 10.1371/journal.pone.0010164

67. Heino TJ, Chagin AS, Savendahl L. The novel estrogen receptor G-proteincoupled receptor 30 is expressed in human bone. J Endocrinol. (2008) 197:R1-6. doi: 10.1677/Joe-07-0629

68. Canonaco M, Giusi G, Madeo A, Facciolo RM, Lappano R, Canonaco A, et al. A sexually dimorphic distribution pattern of the novel estrogen receptor Gprotein-coupled receptor 30 in some brain areas of the hamster. J Endocrinol. (2008) 196:131-8. doi: 10.1677/Joe-07-0392

69. Chagin AS, Savendahl L. GPR30 estrogen receptor expression in the growth plate declines as puberty progresses. J Clin EndocrinolMetab. (2007) 92:487377. doi: 10.1210/jc.2007-0814
70. Gebhardt S, Merkl M, Herbach N, Wanke R, Handler J, Bauersachs S. Exploration of global gene expression changes during the estrous cycle in equine endometrium. Biol Reprod. (2012) 87:136. doi: 10.1095/biolreprod.112.103226

71. Prossnitz ER, Hathaway HJ. What have we learned about GPER function in physiology and disease from knockout mice? J Steroid Biochem Mol Biol. (2015) 153:114-26. doi: 10.1016/j.jsbmb.2015.06.014

72. Kelly MJ, Levin ER. Rapid actions of plasma membrane estrogen receptors. Trends Endocrinol Metab. (2001) 12:152-6. doi: 10.1016/s1043-2760(01)00377-0

73. Funakoshi T, Yanai A, Shinoda K, Kawano MM, Mizukami Y. G protein-coupled receptor 30 is an estrogen receptor in the plasma membrane. Biochem Biophys Res Commun. (2006) 346:904-10. doi: 10.1016/j.bbrc.2006.05.191

74. Meyer MR, Fredette NC, Howard TA, Hu C, Ramesh C, Daniel C, et al. G protein-coupled estrogen receptor protects from atherosclerosis. Scientific Rep. (2014) 4:7564. doi: 10.1038/srep07564

75. Meyer MR, Clegg DJ, Prossnitz ER, Barton M. Obesity, insulin resistance and diabetes: sex differences and role of oestrogen receptors. Acta Physiologica. (2011) 203:259-69. doi: 10.1111/j.1748-1716.2010.02237.x

76. Balhuizen A, Kumar R, Amisten S, Lundquist I, Salehi A. Activation of G protein-coupled receptor 30 modulates hormone secretion and counteracts cytokine-induced apoptosis in pancreatic islets of female mice. Mol Cell Endocrinol. (2010) 320:16-24. doi: 10.1016/j.mce.2010.01.030

77. Ronda AC, Boland RL. Intracellular distribution and involvement of GPR30 in the actions of E2 on C2C12 cells. J Cell Biochem. (2016) 117:793-805. doi: $10.1002 / j$ cb. 25369

78. Gao F, Ma X, Ostmann AB, Das SK. GPR30 activation opposes estrogen-dependent uterine growth via inhibition of stromal ERK1/2 and estrogen receptor alpha $(\mathrm{ER} \alpha)$ phosphorylation signals. Endocrinology. (2011) 152:1434-47. doi: 10.1210/en.2010-1368

79. Maiti K, Paul J, Read M, Chan E, Riley S, Nahar P, Smith R. G-1activated membrane estrogen receptors mediate increased contractility of the human myometrium. Endocrinology. (2011) 152:2448-55. doi: 10.1210/en.2010-0979

80. Lindsey SH, Yamaleyeva LM, Brosnihan KB, Gallagher PE, Chappell MC. Estrogen receptor GPR30 reduces oxidative stress and proteinuria in the salt-sensitive female mRen2. Lewis Hyperten. (2011) 58:665-71. doi: 10.1161/HYPERTENSIONAHA.111.175174

81. Cheng S-B, Graeber CT, Quinn JA, Filardo EJ. Retrograde transport of the transmembrane estrogen receptor, G-protein-coupled-receptor-30 (GPR30/GPER) from the plasma membrane towards the nucleus. Steroids. (2011) 76:892-6. doi: 10.1016/j.steroids.2011.02.018

82. Cheng S-B, Dong J, Pang Y, LaRocca J, Hixon M, Thomas P, et al. Anatomical location and redistribution of $\mathrm{G}$ protein-coupled estrogen receptor-1 during the estrus cycle in mouse kidney and specific binding to estrogens but not aldosterone. Mol Cell Endocrinol. (2014) 382:950-9. doi: 10.1016/j.mce.2013.11.005

83. Akama KT, Thompson LI, Milner TA, McEwen BS. Post-synaptic density95 (PSD-95) binding capacity of G-protein-coupled receptor 30 (GPR30), an estrogen receptor that can be identified in hippocampal dendritic spines. $J$ Biol Chem. (2013) 288:6438-50. doi: 10.1074/jbc.M112.412478

84. Revankar CM, Mitchell HD, Field AS, Burai R, Corona C, Ramesh C, et al. Synthetic estrogen derivatives demonstrate the functionality of intracellular GPR30. ACS Chem Biol. (2007) 2:536-44. doi: 10.1021/cb700072n

85. S-Cheng B, Quinn JA, Graeber CT, Filardo EJ. Down-modulation of the G-protein-coupled estrogen receptor GPER from the cell surface occurs via a trans-Golgi-proteasome pathway. J Biol Chem. (2011) 286:22441-55. doi: 10.1074/jbc.M111.224071

86. Prossnitz ER, Arterburn JB, Sklar LA. GPR30: A G protein-coupled receptor for estrogen. Mol Cell Endocrinol. (2007) 265:138-42. doi: 10.1016/j.mce.2006.12.010

87. Kuiper GG, Carlsson B, Grandien K, Enmark E, Haggblad J, Nilsson S, et al. Comparison of the ligand binding specificity and transcript tissue distribution of estrogen receptors alpha and beta. Endocrinology. (1997) 138:863-70. doi: 10.1210/endo.138.3.4979

88. Ososki AL, Kennelly E, Phytoestrogens J. A review of the present state of research. Phytotherapy Res. (2003) 17:845-69. doi: 10.1002/ptr.1364 
89. Vivacqua A, Bonofiglio D, Recchia AG, Musti AM, Picard D, Andò S, et al. The G protein-coupled receptor GPR30 mediates the proliferative effects induced by $17 \beta$-estradiol and hydroxytamoxifen in endometrial cancer cells. Mol Endocrinol. (2006) 20:631-46. doi: 10.1016/j.bbrc.2012.02.161

90. Filardo EJ, Quinn JA, Bland KI, Frackelton AR. Estrogen-induced activation of Erk-1 and Erk-2 requires the G protein-coupled receptor homolog, GPR30, and occurs via trans-activation of the epidermal growth factor receptor through release of HB-EGF. Mol Endocrinol. (2000) 14:1649-60. doi: 10.1210/me.14.10.1649

91. Petrie WK, Dennis MK, Hu C, Dai D, Arterburn JB, Smith HO, et al. G protein-coupled estrogen receptor-selective ligands modulate endometrial tumor growth. Obstet Gynecol Int. (2013) 2013:472720. doi: $10.1155 / 2013 / 472720$

92. Thomas P, Dong J. Binding and activation of the seven-transmembrane estrogen receptor GPR30 by environmental estrogens: a potential novel mechanism of endocrine disruption. J Steroid Biochem Mol Biol. (2006) 102:175-9. doi: 10.1016/j.jsbmb.2006.09.017

93. Dong S, Terasaka S, Kiyama R. Bisphenol A induces a rapid activation of Erk1/2 through GPR30 in human breast cancer cells. Environ Pollution. (2011) 159:212-8. doi: 10.1016/j.envpol.2010.09.004

94. Chevalier N, Bouskine A, Fenichel P. Bisphenol A promotes testicular seminoma cell proliferation through GPER/GPR30. Intl J Cancer. (2012) 130:241-2. doi: 10.1002/ijc.25972

95. Vivacqua A, Bonofiglio D, Albanito L, Madeo A, Rago V, Carpino A, et al. $17 \beta$-Estradiol, genistein, and 4-hydroxytamoxifen induce the proliferation of thyroid cancer cells through the G protein-coupled receptor GPR30. Mol Pharmacol. (2006) 70:1414-23. doi: 10.1124/mol.106.026344

96. Luo J, Wang A, Zhen W, Wang Y, Si H, Jia Z, et al. Phytonutrient genistein is a survival factor for pancreatic beta-cells via GPR30-mediated mechanism. $J$ Nutr Biochem. (2018) 58:59-70. doi: 10.1016/j.jnutbio.2018.04.018

97. Rowlands DJ, Chapple S, Siow RC, Mann GE. Equol-stimulated mitochondrial reactive oxygen species activate endothelial nitric oxide synthase and redox signaling in endothelial cells: roles for F-actin and GPR30. Hypertension. (2011) 57:833-40. doi: 10.1161/HYPERTENSIONAHA.110.162198

98. Dong WH, Chen JC, He YL, Xu JJ, Mei YA. Resveratrol inhibits K(v)2.2 currents through the estrogen receptor GPR30-mediated PKC pathway. Am J Physiol Cell Physiol. (2013) 305:C547-57. doi: 10.1152/ajpcell.00146.2013

99. Chimento A, Casaburi I, Rosano C, Avena P, De Luca A, Campana C, et al. Oleuropein and hydroxytyrosol activate GPER/GPR30-dependent pathways leading to apoptosis of ER-negative SKBR3 breast cancer cells. Mol NutrFood Res. (2014) 58:478-89. doi: 10.1002/mnfr.201300323

100. Kajta M, Rzemieniec J, Litwa E, Lason W, Lenartowicz M, Krzeptowski W, et al. The key involvement of estrogen receptor beta and G-protein-coupled receptor 30 in the neuroprotective action of daidzein. Neuroscience. (2013) 238:345-60. doi: 10.1016/j.neuroscience.2013.02.005

101. Bologa CG, Revankar CM, Young SM, Edwards BS, Arterburn JB, Kiselyov AS, et al. Virtual and biomolecular screening converge on a selective agonist for GPR30. Nat Chem Biol. (2006) 2:207-12. doi: 10.1038/nchembio775

102. Dennis MK, Field AS, Burai R, Ramesh C, Petrie WK, Bologa CG, et al. Identification of a GPER/GPR30 antagonist with improved estrogen receptor counterselectivity. J Steroid Biochem Mol Biol. (2011) 127:358-66. doi: $10.1016 /$ j.jsbmb.2011.07.002

103. Dennis MK, Burai R, Ramesh C, Petrie WK, Alcon SN, Nayak TK, et al. In vivo effects of a GPR30 antagonist. Nature Chemical Biol. (2009) 5:421-7. doi: 10.1038/nchembio. 168

104. Arterburn JB, Oprea TI, Prossnitz ER, Edwards BS, Sklar LA. Discovery of selective probes and antagonists for $G$ protein-coupled receptors FPR/FPRL1 and GPR30. Curr Topics Medicinal Chem. (2009) 9:1227-36. doi: $10.2174 / 156802609789753608$

105. Lappano R, Mallet C, Rizzuti B, Grande F, Galli G, R., Byrne C, et al. Maggiolini: the peptide ERalpha17p is a GPER inverse agonist that exerts antiproliferative effects in breast cancer cells. Cells. (2019) 8:590. doi: $10.3390 /$ cells 8060590

106. Trichet M, Lappano R, Belnou M, Salazar Vazquez LS, Alves I, Ravault D, et al. Interaction of the anti-proliferative GPER inverse agonist ERalpha17p with the breast cancer cell plasma membrane: from biophysics to biology. Cells. (2020) 9:447. doi: 10.3390/cells9020447
107. Lappano R, Rosano C, Santolla MF, Pupo M, De Francesco EM, De Marco $\mathrm{P}$, et al. Two novel GPER agonists induce gene expression changes and growth effects in cancer cells. Cur Cancer Drug Targets. (2012) 12:531-42. doi: 10.2174/156800912800673284

108. Lappano R, Santolla MF, Pupo M, Sinicropi MS, Caruso A, Rosano C, et al. MIBE acts as antagonist ligand of both estrogen receptor $\alpha$ and GPER in breast cancer cells. Breast Cancer Res BCR. (2012) 14: R12. doi: $10.1186 / \mathrm{bcr} 3096$

109. Revankar CM, Bologa CG, Pepermans RA, Sharma G, Petrie WK, Alcon $\mathrm{SN}$, et al. A selective ligand for estrogen receptor proteins discriminates rapid and genomic signaling. Cell Chem Bbiol. (2019) 26: 1692-702.e5. doi: 10.1016/j.chembiol.2019.10.009

110. Lappano R, De Marco P, De Francesco EM, Chimento A, Pezzi V, Maggiolini M. Cross-talk between GPER and growth factor signaling. J Steroid Biochem Mol Biol. (2013) 137:50-6. doi: 10.1016/j.jsbmb.2013.03.005

111. Pisano A, Santolla MF, De Francesco EM, De Marco P, Rigiracciolo DC, Perri MG, et al. IGF-IR, and EGFR transduction signaling are involved in stimulatory effects of zinc in breast cancer cells and cancerassociated fibroblasts. Mol Carcinog. (2017) 56:580-93. doi: 10.1002/mc. 22518

112. Albanito L, Lappano R, Madeo A, Chimento A, Prossnitz ER, Cappello $A R$, et al. G-protein-coupled receptor 30 and estrogen receptor-alpha are involved in the proliferative effects induced by atrazine in ovarian cancer cells. Environ Health Perspect. (2008) 116:1648-55. doi: 10.1289/ehp. 11297

113. Albanito L, Madeo A, Lappano R, Vivacqua A, Rago V, Carpino A, et al. G protein-coupled receptor 30 (GPR30) mediates gene expression changes and growth response to 17beta-estradiol and selective GPR30 ligand G-1 in ovarian cancer cells. Cancer Res. (2007) 67:1859-66. doi: 10.1158/0008-5472.CAN-06-2909

114. Heublein S, Lenhard M, Vrekoussis T, Schoepfer J, Kuhn C, Friese K, et al. The G-protein-coupled estrogen receptor (GPER) is expressed in normal human ovaries and is upregulated in ovarian endometriosis and pelvic inflammatory disease involving the ovary. Reprod Sci. (2012) 19:1197-204. doi: $10.1177 / 1933719112446085$

115. He YY, Cai B, Yang YX, Liu XL, Wan XP. Estrogenic G protein-coupled receptor 30 signaling is involved in regulation of endometrial carcinoma by promoting proliferation, invasion potential, and interleukin-6 secretion via the MEK/ERK mitogen-activated protein kinase pathway. Cancer Sci. (2009) 100:1051-61.

116. Plante BJ, Lessey BA, Taylor RN, Wang W, Bagchi MK, Yuan L, et al. G protein-coupled estrogen receptor (GPER) expression in normal and abnormal endometrium. Reprod Sci. (2012) 19:684-93. doi: $10.1177 / 19337191114310000034672$

117. Chevalier N, Bouskine A, Fenichel P. Role of GPER/GPR30 in tumoral testicular germ cells proliferation. Cancer Biol Ther. (2011) 12:2-3. doi: $10.4161 /$ cbt.12.1.15726

118. Chevalier N, Vega A, Bouskine A, Siddeek B, Michiels JF, Chevallier $\mathrm{D}$, et al. GPR30, the non-classical membrane $G$ protein related estrogen receptor, is overexpressed in human seminoma and promotes seminoma cell proliferation. PLoS ONE. (2012) 7:e0034672. doi: 10.1371/journal.pone.0034672

119. Chan QKY, Lam HM, Ng CF, Lee AYY, Chan ESY, Ng HK, et al. Activation of GPR30 inhibits the growth of prostate cancer cells through sustained activation of Erk1/2, c-jun/c-fos-dependent upregulation of p21, and induction of G(2) cell-cycle arrest. Cell Death Differ. (2010) 17:1511-23. doi: $10.1038 /$ cdd.2010.20

120. Wang D, Hu L, Zhang G, Zhang L, Chen C. G protein-coupled receptor 30 in tumor development. Endocrine. (2010) 38:29-37. doi: 10.1007/s12020-010-9363-Z

121. Molina L, Bustamante FA, Bhoola KD, Figueroa CD, Ehrenfeld P. Possible role of phytoestrogens in breast cancer via GPER-1/GPR30 signaling. Clin Sci (Lond). (2018) 132:2583-98. doi: 10.1042/CS20180885

122. Qian H, Xuan J, Liu Y, Shi G. Function of G-protein-coupled estrogen receptor-1 in reproductive system tumors. J Immunol Res. (2016) 2016:7128702. doi: 10.1155/2016/7128702

123. Feldman RD, Limbird LE. GPER (GPR30): A nongenomic receptor (GPCR) for steroid hormones with implications for cardiovascular 
disease and cancer. Ann Rev Pharmacol Toxicol. (2017) 57:567-84. doi: 10.1146/annurev-pharmtox-010716-104651

124. De Francesco EM, Pellegrino M, Santolla MF, Lappano R, Ricchio E, Abonante $\mathrm{S}$, et al. GPER mediates activation of HIF1 $\alpha /$ VEGF signaling by estrogens. Cancer Res. (2014) 74:4053-64. doi: 10.1158/0008-5472.CAN-13-3590

125. Ignatov $\mathrm{T}$, Modl S, Thulig M, Weißenborn $\mathrm{C}$, Treeck $\mathrm{O}$, Ortmann $\mathrm{O}$, et al. GPER-1 acts as a tumor suppressor in ovarian cancer. J Ovar Res. (2013) 6:51. doi: 10.1186/1757-2215-6-51

126. Teng J, Wang ZY, Prossnitz ER, Bjorling DE. The G protein-coupled receptor GPR30 inhibits human urothelial cell proliferation. Endocrinology. (2008) 149:4024-34. doi: 10.1210/en.2007-1669

127. Kushner PJ, Agard DA, Greene GL, Scanlan TS, Shiau AK, Uht RM, et al. Estrogen receptor pathways to AP-1. J Steroid Biochem Mol Biol. (2000) 74:311-7. doi: 10.1016/s0960-0760(00)00108-4

128. Wei W, Chen ZJ, Zhang KS, Yang XL, Wu YM, Chen XH, et al. The activation of G protein-coupled receptor 30 (GPR30) inhibits proliferation of estrogen receptor-negative breast cancer cells in vitro and in vivo. Cell Death Dis. (2014) 5:e1428. doi: 10.1038/cddis.2014.398

129. Wu J, Miao C, Lv X, Zhang Y, Li Y, Wang D. Estrogen regulates forkhead transcription factor 2 to promote apoptosis of human ovarian granulosa-like tumor cells. J Steroid Biochem Mol Biol. (2019) 194:105418. doi: 10.1016/j.jsbmb.2019.105418

130. Chimento A, Sirianni R, Delalande C, Silandre D, Bois C, Ando S, et al. 17 beta-Estradiol activates rapid signaling pathways involved in rat pachytene spermatocytes apoptosis through GPR30 and ER alpha. Mol Cell Endocrinol. (2010) 320:136-44. doi: 10.1016/j.mce.2010.01.035

131. Sirianni R, Chimento A, Ruggiero C, De Luca A, Lappano R, Ando $\mathrm{S}$, et al. The novel estrogen receptor, G protein-coupled receptor 30 , mediates the proliferative effects induced by 17beta-estradiol on mouse spermatogonial GC-1 cell line. Endocrinology. (2008) 149:5043-51. doi: 10.1210/en.2007-1593

132. Otto C, Rohde-Schulz B, Schwarz G, Fuchs I, Klewer M, Brittain D, et al. $\mathrm{G}$ protein-coupled receptor 30 localizes to the endoplasmic reticulum and is not activated by estradiol. Endocrinology. (2008) 149:4846-56. doi: 10.1210/ en.2008-0269

133. Wang H, Sun X, Chou J, Lin M, Ferrario CM, Zapata-Sudo G, et al. Cardiomyocyte-specific deletion of the $\mathrm{G}$ protein-coupled estrogen receptor (GPER) leads to left ventricular dysfunction and adverse remodeling: a sexspecific gene profiling analysis. Biochim Biophys Acta Mol Basis Dis. (2017) 1863:1870-82. doi: 10.1016/j.bbadis.2016.10.003

134. Meyer MR, Baretella O, Prossnitz ER, Barton M. Dilation of epicardial coronary arteries by the $\mathrm{G}$ protein-coupled estrogen receptor agonists G-1 and ICI 182,780. Pharmacology. (2010) 86:58-64. doi: 10.1159/000315497

135. Lindsey SH, Cohen JA, Brosnihan KB, Gallagher PE, Chappell MC. Chronic treatment with the G protein-coupled receptor 30 agonist G-1 decreases blood pressure in ovariectomized mRen2.Lewis rats. Endocrinology. (2009) 150:3753-8. doi: 10.1210/en.2008-1664

136. Haas E, Bhattacharya I, Brailoiu E, Damjanovic M, Brailoiu GC, Gao $\mathrm{X}$, et al. Regulatory role of $\mathrm{G}$ protein-coupled estrogen receptor for vascular function and obesity. Circ Res. (2009) 104:288-91. doi: 10.1161/CIRCRESAHA.108.190892

137. Meyer MR, Prossnitz ER, Barton M. GPER/GPR30 and regulation of vascular tone and blood pressure. Immunol Endocr Metab Agents Med Chem. (2011) 11: 255-61. doi: 10.2174/1871522211108040255

138. Debortoli AR, Rouver WDN, Delgado NTB, Mengal V, Claudio ERG, Pernomian L, et al. GPER modulates tone and coronary vascular reactivity in male and female rats. J Mol Endocrinol. (2017) 59:171-80. doi: 10.1530/JME-16-0117

139. Meyer MR, Field AS, Kanagy NL, Barton M, Prossnitz ER. GPER regulates endothelin-dependent vascular tone and intracellular calcium. Life Sci. (2012) 91:623-7. doi: 10.1016/j.lfs.2012.01.007

140. Ogola BO, Zimmerman MA, Sure VN, Gentry KM, Duong JL, Clark GL, et al. $\mathrm{G}$ protein-coupled estrogen receptor protects from angiotensin II-induced increases in pulse pressure and oxidative stress. Front Endocrinol. (2019) 10:586. doi: 10.3389/fendo.2019.00586

141. Luine VN. Estradiol and cognitive function: past, present and future. Horm Behav. (2014) 66:602-18. doi: 10.1016/j.yhbeh.2014.08.011
142. Marchese E, Corvino V, Di Maria V, Furno A, Giannetti S, Cesari E, et al. The neuroprotective effects of $17 \beta$-estradiol pretreatment in a model of neonatal hippocampal injury induced by trimethyltin. Front Cell Neurosci. (2018) 12:385. doi: 10.3389/fncel.2018.00385

143. Spencer JL, Waters EM, Romeo RD, Wood GE, Milner TA, McEwen BS. Uncovering the mechanisms of estrogen effects on hippocampal function. Front Neuroendocrinol. (2008) 29:219-37. doi: 10.1016/j.yfrne.2007.08.006

144. Frick KM. Estrogens and age-related memory decline in rodents: what have we learned and where do we go from here? Horm Behav. (2009) 55:2-23. doi: 10.1016/j.yhbeh.2008.08.015

145. Lebesgue D, Traub M, De Butte-Smith M, Chen C, Zukin RS, Kelly MJ, et al. Acute administration of non-classical estrogen receptor agonists attenuates ischemia-induced hippocampal neuron loss in middle-aged female rats. PLoS ONE. (2010) 5:e8642. doi: 10.1371/journal.pone.0008642

146. Roque C, Mendes-Oliveira J, Baltazar G. G protein-coupled estrogen receptor activates cell type-specific signaling pathways in cortical cultures: relevance to the selective loss of astrocytes. J Neurochem. (2019) 149: 27-40. doi: $10.1111 /$ jnc. 14648

147. Machado GDB, de Freitas BS, Florian LZ, Monteiro RT, Gus H, Schröder N. G protein-coupled oestrogen receptor stimulation ameliorates iron- and ovariectomy-induced memory impairments through the cAMP/PKA/CREB signalling pathway. J Neuroendocrinol. (2019) 31:e12780. doi: 10.1111/jne. 12780

148. Kim J, Szinte JS, Boulware MI, Frick KM. 17beta-estradiol and agonism of g-protein-coupled estrogen receptor enhance hippocampal memory via different cell-signaling mechanisms. J Neurosci. (2016) 36:3309-21. doi: 10.1523/JNEUROSCI.0257-15.2016

149. Liu SH, Mauvais-Jarvis F. Rapid, nongenomic estrogen actions protect pancreatic islet survival. Islets. (2009) 1:273-5. doi: 10.4161/isl.1. 3.9781

150. Liu S, Le May C, Wong WP, Ward RD, Clegg DJ, Marcelli M, et al. Importance of extranuclear estrogen receptor-alpha and membrane G protein-coupled estrogen receptor in pancreatic islet survival. Diabetes. (2009) 58:2292-302. doi: 10.2337/db09-0257

151. Meyer MR, Haas E, Prossnitz ER, Barton M. Non-genomic regulation of vascular cell function and growth by estrogen. Mol Cell Endocrinol. (2009) 308:9-16. doi: 10.1016/j.mce.2009.03.009

152. Liu S, Mauvais-Jarvis F. Minireview: estrogenic protection of betacell failure in metabolic diseases. Endocrinology. (2010) 151:859-64. doi: 10.1210/en.2009-1107

153. Fu Z, Zhang W, Zhen W, Lum H, Nadler J, Bassaganya-Riera J, et al. Genistein induces pancreatic beta-cell proliferation through activation of multiple signaling pathways and prevents insulin-deficient diabetes in mice. Endocrinology. (2010) 151:3026-37. doi: 10.1210/en.2009-1294

154. Wang AH, Luo J, Moore W, Alkhalidy H, Wu L, Zhang JH, et al. GPR30 regulates diet-induced adiposity in female mice and adipogenesis in vitro. Scientific Rep. (2016) 6:302. doi: 10.1038/srep34302

155. Thigpen JE, Setchell KD, Kissling GE, Locklear J, Caviness GF, Whiteside $\mathrm{T}$, et al. The estrogenic content of rodent diets, bedding, cages, and water bottles and its effect on bisphenol A studies. J Am Assoc Lab Anim Sci. (2013) 52:130-41.

156. Si H, Liu D. Genistein, a soy phytoestrogen, upregulates the expression of human endothelial nitric oxide synthase and lowers blood pressure in spontaneously hypertensive rats. J Nutr. (2008) 138:297-304. doi: 10.1093/jn/138.2.297

157. Rietjens I, Louisse J, Beekmann K. The potential health effects of dietary phytoestrogens. Br J Pharmacol. (2017) 174:1263-80. doi: 10.1111/bph.13622

158. Qiu J, Bosch MA, Tobias SC, Grandy DK, Scanlan TS, Ronnekleiv OK, et al. Rapid signaling of estrogen in hypothalamic neurons involves a novel Gprotein-coupled estrogen receptor that activates protein kinase C. J Neur. (2003) 23:9529-40. doi: 10.1523/JNEUROSCI.23-29-09529.2003

159. Qiu J, Bosch MA, Tobias SC, Krust A, Graham SM, Murphy SJ, et al. A G-protein-coupled estrogen receptor is involved in hypothalamic control of energy homeostasis. J Neur. (2006) 26:5649-55. doi: 10.1523/Jneursci.0327-06.2006

160. Heine PA, Taylor JA, Iwamoto GA, Lubahn DB, Cooke PS. Increased adipose tissue in male and female estrogen receptor-alpha knockout mice. Proc Natl Acad Sci USA. (2000) 97:12729-34. doi: 10.1073/pnas.97.23.12729 
161. Ding Q, Gros R, Limbird LE, Chorazyczewski J, Feldman RD. Estradiolmediated ERK phosphorylation and apoptosis in vascular smooth muscle cells requires GPR 30. Am J Physiol Cell Physiol. (2009) 297:C1178-87. doi: 10.1152/ajpcell.00185.2009

162. Chakrabarti S, Davidge ST. G-protein coupled receptor 30 (GPR30): a novel regulator of endothelial inflammation. PLoS ONE. (2012) 7:e52357. doi: 10.1371/journal.pone.0052357

163. Saito T, Ciobotaru A, Bopassa JC, Toro L, Stefani E, Eghbali M. Estrogen contributes to gender differences in mouse ventricular repolarization. Circ Res. (2009) 105:343-52. doi: 10.1161/CIRCRESAHA.108.190041

164. Bronson FH, Desjardins C. Circulating concentrations of FSH. LH, estradiol, and progesterone associated with acute, male-induced puberty in female mice. Endocrinology. (1974) 94:1658-1668.

165. Nilsson ME, Vandenput L, Tivesten A, Norlen AK, Lagerquist MK, Windahl $\mathrm{SH}$, et al. Measurement of a comprehensive sex steroid profile in rodent serum by high-sensitive gas chromatography-tandem mass spectrometry. Endocrinology. (2015) 156:2492-502. doi: 10.1210/en.2014-1890

166. Pedram A, Razandi M, Levin ER. Nature of functional estrogen receptors at the plasma membrane. Mol Endocrinol. (2006) 20:1996-2009. doi: 10.1210/me.2005-0525

167. Ahola TM, Manninen T, Alkio N, Ylikomi T. G protein-coupled receptor 30 is critical for a progestin-induced growth inhibition in MCF-7 breast cancer cells. Endocrinology. (2002) 143:3376-84. doi: 10.1210/en.2001-211445

168. Wang Z, Zhang X, Shen P, Loggie BW, Chang Y, Deuel TF. Identification, cloning, and expression of human estrogen receptor- $\alpha 36$, a novel variant of human estrogen receptor- $\alpha 66$. Biochem Biophys Res Commun. (2005) 336:1023-7. doi: 10.1016/j.bbrc.2005.08.226

169. Pedram A, Razandi M, Blumberg B, Levin ER. Membrane and nuclear estrogen receptor $\alpha$ collaborate to suppress adipogenesis but not triglyceride content. FASEB J. (2015) 30:230-40. doi: 10.1096/fj.15274878

170. Omarjee S, Jacquemetton J, Poulard C, Rochel N, Dejaegere A, Chebaro $\mathrm{Y}$, et al. The molecular mechanisms underlying the ER $\alpha$-36-mediated signaling in breast cancer. Oncogene. (2017) 36:2503. doi: 10.1038/onc. 2016.415

171. Levin ER. Membrane oestrogen receptor alpha signalling to cell functions. $J$ Physiol. (2009) 587:5019-23. doi: 10.1113/jphysiol.2009.177097

172. Kang L, Zhang X, Xie Y, Tu Y, Wang D, Liu Z, Wang Y. Involvement of estrogen receptor variant ER- $\alpha 36$, not GPR30, in nongenomic estrogen signaling. Mol Endocrinol. (2010) 24:709-21. doi: 10.1210/me.2009-0317

173. Gingerich S, Kim G, Chalmers J, Koletar M, Wang X, Wang Y, Belsham D. Estrogen receptor alpha and G-protein coupled receptor 30 mediate the neuroprotective effects of $17 \beta$-estradiol in novel murine hippocampal cell models. Neuroscience. (2010) 170:54-66. doi: 10.1016/j.neuroscience.2010.06.076

174. Levin ER. G protein-coupled receptor 30: estrogen receptor or collaborator? Endocrinology. (2009) 150:1563-5. doi: 10.1210/en.2008-1759

Conflict of Interest: The authors declare that the research was conducted in the absence of any commercial or financial relationships that could be construed as a potential conflict of interest.

Copyright (C) 2020 Luo and Liu. This is an open-access article distributed under the terms of the Creative Commons Attribution License (CC BY). The use, distribution or reproduction in other forums is permitted, provided the original author(s) and the copyright owner(s) are credited and that the original publication in this journal is cited, in accordance with accepted academic practice. No use, distribution or reproduction is permitted which does not comply with these terms. 